\title{
Effect of a bradykinin potentiating factor separated from honey bee venom on thyroid gland and testis in hypothyroid white rats
}

\author{
Elsabry Abu Amra, Sohir Ali Abd El Rehim, Fakhr Mostafa Lashein* and Heba Seleem Shoaeb
}

\begin{abstract}
Background: Animal venoms have been known as a source of drugs beneficial to human health. Accordingly, this study was designed to determine the effect of bradykinin potentiating factor (BPF) separated from honey bee venom, Apis mellifera on histological structure, thyroid and male sex hormones of the thyroid gland and testis in a model of hypothyroid male white rats induced by carbimazole.

Results: This study includes male rats divided into 6 main and sub-groups (10 rats in each group). Control group, carbimazole group, levothyroxine group, BPF group, carbimazole group treated with levothyroxine and carbimazole group treated with BPF. At the end of experiments (60 days) rats were sacrificed and dissected; the blood was collected for determination of thyroid and male sex hormones. Also, the thyroid gland and testis were taken to histological study. The results indicated that, carbimazole group showed a highly significant decrease in thyroid hormones (T4, T3, Ft4 and Ft3) and male sex hormones (LH, FSH and testosterone), but a significant increase in TSH compared to control group. The results revealed that, treated groups with levothyroxine or BPF have significant increase in thyroid and male sex hormones and significant decreasein TSH. A significant improvement was detected in co-treated groups (hypothyroid groups) with levothyroxine or (BPF). Also, the present study showed a histopathological change in thyroid gland and testis of hypothyroid male rats.
\end{abstract}

Conclusion: Treated hypothyroid rats with levothyroxine as a drug and BPF as a natural product showed an improvement of these complications induced by carbimazole in thyroid gland and testis. Therefore, BPF may be benefical in treatment of hypothyroidism.

Keywords: Hypothyroidism, Carbimazole, Levothyroxine, Bee venom, BPF, Thyroid gland, Testis

\section{Background}

Hypothyroidism is one of the progressive disorders that presents with diverse degrees of thyroid failure and metabolic consequences. Hypothyroidism is a disturbance of thyroid activity results usually from damage, removal or inhibition of the function of the thyroid gland (Braverman \& Utiger, 2005; Daniels \& Dayan, 2006; Mitrou et al., 2011). The reduced secretion of $\mathrm{T} 3$ and $\mathrm{T} 4$ is accompanied by inhibition of many functions of organs and lead

*Correspondence: Flashein@yahoo.com

Zoology Department, Faculty of Science, Sohag University, Sohag, Egypt to restructuring thyroid gland (Fadeev, 2012; Mancini et al., 2013).Thyroid hormones are iodine containing amine hormones T4 or (thyroxine) and T3 or (triiodothyronine) (Diekman et al., 2000). These steroidal hormones play a role in the cardiovascular, nervous, immune and reproductive system development and function (Choksi et al., 2003; Krassas, 2000).

Nowadays, bee venom from honey bee has become the focus of interest as it is used as an alternative and preventive medicine for the treatment of a number of clinical cases. It contains active substances including polypeptides, amines and enzymes that have many biochemical and pharmacological activity (Gauldie et al., 1976; 
Lariviere \& Melzack, 1996) those express their potency and medical efficacy. Bee venom was revealed to be effective in healing and treating several ailments including different rheumatic disorders, neurological disorders (Roh et al., 2004), dermatological conditions (Kim, 2004), and tumors of many different types of malignant diseases (Luiet al., 2002; Oršolić et al., 2003) as it stimulates natural immunity through activation of the pituitary and adrenal gland (Nermine \& Abeer, 2009).

Bradykinin stimulates the synthesis of prolactin and growth hormone (Chihara et al., 1982) and induces vascular permeability and mitogenesis (Wu et al., 2002).The growth hormone and the growth factors increase protein synthesis and stimulate the proliferation of mammalian cells (Montogomery et al., 1980). BK acts as a pain mediator and as a modulator of animal cell proliferation (Roberts, 1989).BPFs potentiate the effects of BK both in vivo and in vitro (Seleem, 2003). Several active polypeptides such as kinin and BPFs have been isolated from the venom of some terrestrial and marine animals (ELDefrawi et al., 1998; Guo et al., 1999; Abu-amra, 2015). $\mathrm{BPF}$ is used also for accelerating the generation of thymus and spleen cellularity without noticeable toxic effects in non-irradiated control animals. This is noticed by injection of BPF in sublethally-irradiated and non-irradiated Guinea pigs (Salman, 2002). Also, bee venom and its bradykinin-potentiating factor are therapeutic agents in the neurodegenerative diseases in which $\alpha$-synucloin plays the effective role in Parkinson's disease (Lashein et al., 2018). In addition, bradykinin-potentiating peptides are considered a useful tool in developing antihypertensive drugs to expand the range of therapies to control hypertension (Lewis \& Garcia, 2003). BPF was also found to promote vasodilation, reduce blood pressures, and increase vascular permeability (Camargo et al., 2012; Jain, 2003; Sonveaux, 2008).Accordingly, the present study was designed to evaluate the effect of BPF separated from honeybee venom on thyroid gland and testis in the induced hypothyroid rats.

\section{Methods}

\section{Chemicals}

Carbimazole was obtained from chemical industries Development (CID). Levothyroxine was purchased from Mercury pharma Group.

\section{Bradykinin-potentiating factor (BPF)}

Bee venom of Apis melifera was obtained from the Faculty of agriculture, Assuit University. Bradykinin potentiating factor (BPF) was isolated from bee venom according to the chemical methods of Ferreira (1965). BPF was dissolved in $0.9 \mathrm{~N}$ saline of $\mathrm{NaCl}$ before using.

\section{Animals}

60 healthy adult male albino rats (180-200 g) were obtained from Zoology department, Faculty of Science, Sohag University for experimentation. Animals were kept in the laboratory under normal conditions of light, temperature, humidity with access of food and water for two weeks then divided into 6 main and sub-groups.

\section{Animal grouping}

Animals were classified into six main and sub-groups. The first main group (G1) composed of 10 animals served as a negative control group. The second main group composed of 30 animals administrated with carbimazole orally $(0.05 \mathrm{mg} / \mathrm{kg} \mathrm{b.wt})$ daily according to Mustafa et al. (2015) for 30 days inducing hypothyroidism. After that, this main group was divided into three sub-groups (G2, G5 and G6). G2 used as a positive control group (hypothyroid group). The fifth and sixth sub-groups (G5 and G6) treated with levothyroxine $(100 \mu \mathrm{g} / \mathrm{kg}$ b.wt $)$ and BPF (2.314 mg/kg b.wt) according to Abd Elazem et al. (2016) and Abu-amra et al. (2018), respectively. The third main group (G3) was administrated orally intubation to levothyroxine daily $(100 \mu \mathrm{g} / \mathrm{kg}$ b.wt) for 30 days to study the effects of levothyroxine only on this group. The fourth main group (G4) composed of 10 animals injected intraperitonally (i.p.) with BPF $(2.314 \mathrm{mg} / \mathrm{kg}$ b.wt $)$ daily for 30 days.

\section{Processing}

After another 30 days from treatment, the animals were sacrificed and dissected. All the blood samples collected from the heart. The blood sample taken in a plastic tube without anti-coagulant to obtain clear serum for immunoassay of thyroid and male sex hormones.

From each animal, thyroid gland and testis of studied groups were fixed in carnoy's fixative, dehydrated in ethyl alcohol, cleared in methyle benzoate, infilterated in paraffin wax at $60{ }^{\circ} \mathrm{C}$ in oven for $6 \mathrm{~h}$, mounted in paraffin wax sections were cut at $7 \mu$ thick by microtome (Leica), the sections were mounted on the normal slides. Mounted sections were stained with hematoxylin and eosin for general histology (Drury \& Wallington, 1976). Sections were dehydrated in ascending grade of ethanol, cleared in xylene and mounted with DPX. The selected stained sections were photographed and processed as required.

\section{Immune-assays}

Immune analysis for thyroid hormones (T3, T4, fT3, fT4 and TSH) and male sex hormones (LH, FSH and Testosterone) were detected. These hormones were measured using TOSOH; AIA-600. All these hormones are ELISA kits and purchased from Biocheck, Inc Company, 
Foster city, U.S.A. T4, T3, fT4 and fT3 were immuneassay according to Wisdom (1976). TSH was determined according to Soos and Siddle (1982). FSH was detected according to Rèbar et al. (1982). LH was determined according to Uotila et al. (1981). Testosterone was detected according to Sauer et al. (1981).

\section{Statistical analysis}

Results are presented as means \pm SE for comparison of different experimental animal groups and control ones. Student's t-test was used and the results were calculated by using origin program (version 6). Significance difference between control and treated groups $n=8$.

\section{Results}

\section{T4, T3, Ft4, Ft3 and TSH levels}

The data obtained in Table 1 showed that, the male albino rats treated with carbimazole has a highly significant decrease $(P<0.001)$ in all parameters except TSH in which a highly significant increase $(P<0.001)$ compared to control group. While, in levothyroxine and BPF treated groups, a highly significant and significant increase $(P<0.001, P<0.05)$ were detected in all parameters but in TSH showed a highly significant decrease $(P<0.001)$ compared to control group. Also, non-significant and significant change $(P>0.05, P<0.05)$ in carbimazole cotreatedwith levothyroxine or BPF groups compared to control group were revealed. Highly significant differences were detected in all tested groups compared to carbimazol group.

\section{Thyroid gland}

Histological sections of normal thyroid gland revealed follicles of different size. Large follicles were located in the peripheral zone and those with small dimensions were noted at the central part of the gland. Their wall consisted of a low cuboidal epithelium of simple type.The interstitial connective tissue of the gland is represented by thin septa between the follicles (Fig. 1a). In carbimazole administrated group, empty follicles those are devoted of colloid secretion were noted (Fig. 1b). In addition, epithelial height of the follicle cells is cleary observed as columnar cells compared to low cuboidal cells of control (Fig. 1b). In bradykinin potentiating factor- and levothyroxine-treated animals, thyroid glands presented with follicles of various sizes with a dominance of large and distended follicles with colloid secretion were noted. The thyroid epithelium was flattened and squamous in

Table 1 Effect of BPF (2.314 mg/kg b.w) and Levothyroxine (100 $\mu \mathrm{g} / \mathrm{kg}$ b.w) on serum T4, T3, Ft4, Ft3 and TSH levels of male albino rats induced by carbimazole $(0.05 \mathrm{mg} / \mathrm{kg}$ b.w) for 60 days in different groups

\begin{tabular}{|c|c|c|c|c|c|c|}
\hline Parameters & Control & Car & Levo & BPF & Car + Levo & $\mathrm{Car}+\mathrm{BPF}$ \\
\hline \multicolumn{7}{|l|}{$\mathrm{T} 4 \mu \mathrm{g} / \mathrm{mL}$} \\
\hline Mean \pm SE & $8.5 \pm 1.7$ & $3.95 a^{* *} \pm 0.8$ & $20 a b^{* *} \pm 1.67$ & $15.2 \mathrm{ab}^{* *} \pm 2.29$ & $7.6 b^{* *} \pm 1.17$ & $8.0 b^{* *} \pm 1.12$ \\
\hline$\%$ of change (1) & & -53.5 & +135.3 & +78.8 & -10.5 & -5.88 \\
\hline$\%$ of change (2) & & & +406 & +284 & +284.8 & +102.5 \\
\hline \multicolumn{7}{|l|}{$\mathrm{T} 3 \mathrm{ng} / \mathrm{mL}$} \\
\hline Mean \pm SE & $1.75 \pm 0.4$ & $0.5 a^{* *} \pm 0.2$ & $4.68 a b^{* *} \pm 0.5$ & $5.3 a b^{* *} \pm 0.57$ & $2.23 a^{*} b^{* *} \pm 0.56$ & $2.11 b^{* *} \pm 0.49$ \\
\hline$\%$ of change (1) & & -71.4 & +162.8 & +202.8 & +27.4 & +20.6 \\
\hline$\%$ of change (2) & & & +820 & +960 & +346 & +322 \\
\hline \multicolumn{7}{|l|}{ FT4 ng/dL } \\
\hline Mean \pm SE & $1.34 \pm 0.16$ & $0.55 a^{* *} \pm 0.08$ & $1.76 a^{*} b^{* *} \pm 0.11$ & $2.3 a b^{* *} \pm 0.24$ & $1.2 b^{* *} \pm 0.14$ & $1.6 b^{* *} \pm 0.19$ \\
\hline$\%$ of change (1) & & -58.9 & +31.3 & +71.6 & -10.4 & +19.4 \\
\hline$\%$ of change (2) & & & +220 & +318 & +118 & +190.9 \\
\hline \multicolumn{7}{|l|}{$\mathrm{FT} 3 \mathrm{pg} / \mathrm{mL}$} \\
\hline Mean \pm SE & $2.93 \pm 0.24$ & $1.35 a^{* *} \pm 0.06$ & $3.6 a^{*} b^{* *} \pm 0.29$ & $4.08 a^{*} b^{* *} \pm 0.17$ & $3.26 b^{* *} \pm 0.2$ & $4.2 a^{*} b^{* *} \pm 0.48$ \\
\hline$\%$ of change (1) & & -53.9 & +22.86 & +39.24 & +11.26 & +43.3 \\
\hline$\%$ of change (2) & & & +166.6 & +202.2 & +141.48 & +211 \\
\hline \multicolumn{7}{|l|}{$\mathrm{TSH} \mu \mathrm{lu} / \mathrm{mL}$} \\
\hline Mean $\pm S E$ & $3.3 \pm 0.33$ & $20.6 a^{* *} \pm 0.89$ & $1.23 a b^{* *} \pm 0.25$ & $0.98 a b^{* *} \pm 0.17$ & $5.4 a^{* *} b^{*} \pm 0.82$ & $6.3 a b^{* *} \pm 0.61$ \\
\hline$\%$ of change (1) & & +524 & -62.7 & -70.3 & +62.4 & +90.9 \\
\hline$\%$ of change (2) & & & -94 & -95 & -37.9 & -69 \\
\hline
\end{tabular}

Significant difference between control and different groups. $N=8 .{ }^{*} P<0.05$ Significant. ${ }^{*} P<0.001$ Highly Significant. Non-Significant $P>0.05 . \%$ of change (1) different from normal control group $\mathrm{G} 1 . \%$ of change (2) different from carbimazole group $\mathrm{G} 2$

a Significant different from control group

${ }^{\mathrm{b}}$ Significant different from carbimazole group 

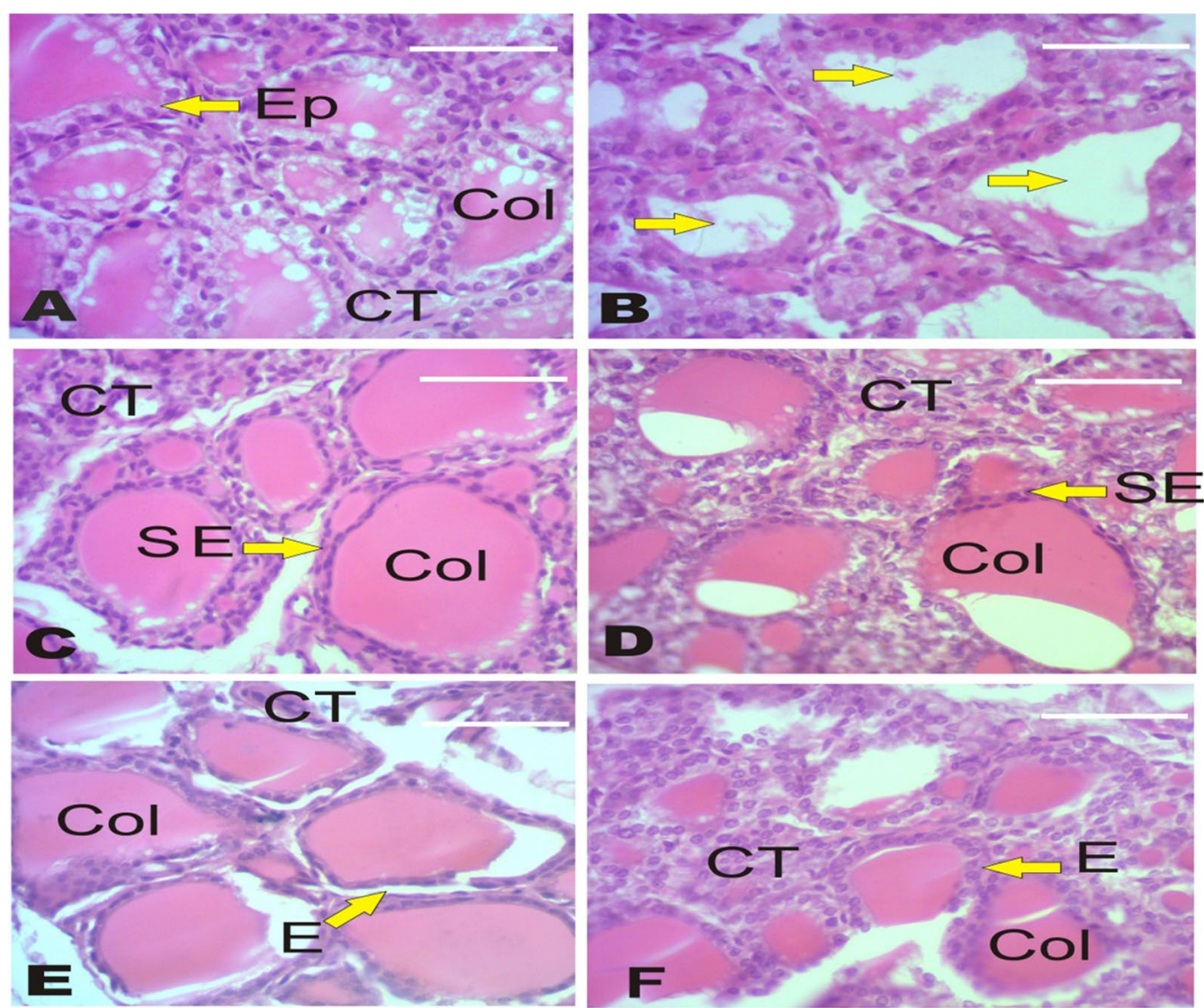

Fig. 1 Photomicrographs of histological sections through the thyroid gland show cuboidal epithelium (Ep), homogenous eosinophilic colloid (Col), connective tissue septa (CT) between follicles in control (a). Negative homogenous eosinophilic colloid (arrows) in carbimazole- treated animals (b). Large quantity of homogenous- colloid (Col) with squamous epitheloidal cells (SE) in bradykinin potentiating factor and levothyroxine- treated animals were noted $(\mathbf{c}, \mathbf{d})$. Tissue recovery with homogenous colloid (Col) of the follicles in combined treatment with either bradykinin potentiating factor or levothyroxine was noticed in $\mathbf{e}$, $\mathbf{f}$. H\&E stain, scale bar $20 \mu \mathrm{m}$

the follicles. Cell nuclei were also flattened. Follicles contained a large quantity of homogeneous, eosinophilic colloid. The interstitium of the gland presented with scanty connective tissue between the follicles, as compared with the control group (Fig. 1c, d). Tissue recovery of thyroid section is best observed in co-administration of both BPF and levothyroxine with carbimazole (Fig. 1e, f) compared to carbimazole administrated group.

\section{LH, FSH and testosterone levels}

In comparison with the normal control group, the results indicated that carbimazole group showed a significant decrease $(P<0.05)$ in $\mathrm{LH}, \mathrm{FSH}$ and testosterone levelscompared to control group. In levothyroxine and BPF groups, a significant and highly significant increase $(P<0.05, P<0.001)$ respectively, were detected in $\mathrm{LH}$ and FSH levels compared to control.In testosterone level,a non-significant and a significant increase showed in levothyroxine and BPF groups respectively, compared to control group. In carbimazole co-treated with either levothyroxine or BPF, non-significant difference showed in LH, FSH and testosterone levels compared to control group. Significant and highly significant changes were also detected in all treated and co-treated groups compared to carbimazole in three parameters. These data is shown in Table 2.

\section{Histological study \\ Testis}

Normal histological structure of testicular tissue section showing normal seminiferous tubules lined with germinal epithelia. Each tubule contains different stages of spermatogenic cells. Spermatogenesis was regular and the lumen of seminiferous tubules was fully packed with sperms. The seminiferous tubules contain several layers of cells representing spermatogonia which lie along the periphery of the tubules. Primary- spermatogonia are the largest cells in contact with the basal lamina and 
Table 2 Effect of BPF (2.314 mg/kg b.w) and Levothyroxine (100 $\mu \mathrm{g} / \mathrm{kg}$ b.w) on serum LH, FSH and testosterone levelsof male albino rats induced by carbimazole $(0.05 \mathrm{mg} / \mathrm{kg}$ b.w) for 60 days in different groups

\begin{tabular}{|c|c|c|c|c|c|c|}
\hline Parameter & Control & Car & Levo & BPF & Car + Levo & $\mathrm{Car}+\mathrm{BPF}$ \\
\hline \multicolumn{7}{|l|}{$\mathrm{LH} \mu \mathrm{IU} / \mathrm{mL}$} \\
\hline Mean \pm SE & $6.35 \pm 0.68$ & $3.88^{\mathrm{a}^{*}} \pm 0.64$ & $8.46^{\mathrm{a}^{*} b^{* *}} \pm 1.14$ & $10.47^{\mathrm{ab} \mathrm{b}^{* *}} \pm 0.66$ & $6.45^{\mathrm{b}^{* *}} \pm 0.55$ & $7.2^{b^{* *}} \pm 0.72$ \\
\hline$\%$ of change (1) & & -38.8 & +33.2 & +64.8 & +1.57 & +13.5 \\
\hline$\%$ of change (2) & & & +118 & +169.8 & +66.2 & +85.58 \\
\hline \multicolumn{7}{|l|}{$\mathrm{FSH} \mu \mathrm{IU} / \mathrm{mL}$} \\
\hline Mean \pm SE & $8.8 \pm 0.92$ & $5.0^{\mathrm{a}^{*}} \pm 0.42$ & $11.4^{\mathrm{a}^{*} \mathrm{~b}^{* *}} \pm 1.2$ & $19.4^{\mathrm{ab}^{* *}} \pm 1.79$ & $10.0^{b^{* *}} \pm 0.76$ & $9.65^{b^{* *}} \pm 0.7$ \\
\hline$\%$ of change (1) & & -42 & +29.7 & +120 & +13.6 & +9.65 \\
\hline$\%$ of change (2) & & & +123.9 & +280.4 & +100 & +93 \\
\hline \multicolumn{7}{|l|}{ Testosterone ng/dL } \\
\hline Mean \pm SE & $250 \pm 3.6$ & $190.2^{\mathrm{a}^{*}} \pm 3.8$ & $277.8^{\mathrm{b}^{*}} \pm 2$ & $353.5^{a^{*} b^{* *}} \pm 3.0$ & $239.3^{b^{*}} \pm 3.6$ & $246.6^{b^{*}} \pm 3.0$ \\
\hline$\%$ of change (1) & & -24 & +11 & +41.4 & -4.3 & -1.4 \\
\hline$\%$ of change (2) & & & +46 & +85.5 & +25.8 & +29.6 \\
\hline
\end{tabular}

Significant difference between control and different groups. $\mathrm{N}=8$

${ }^{*} P<0.05$ Significant. ${ }^{* *} P<0.001$ Highly Significant. Non-Significant $P>0.05 . \%$ of change (1) different from normal control group G1.\% of change (2) different from carbimazole group $\mathrm{G} 2$

a Significant different from control group

${ }^{\text {b }}$ Significant different from carbimazole group

they are oval shaped with prominant nuclei. Secondaryspermatogonia are smaller than the previous cells. The primary spermatocytes are characterized by large spherical nuclei. The secondary spermatocytes are smaller in size than primary spermatocytes. Aggregated spermatozoa lie in the lumen of tubules (Fig. 2a). The section of testis in hypothyroid rats showed irregular seminiferous tubules, inhibition of spermatogenesis, degenerative changes and sloughing in spermatogenic cells (Fig. 2b). Treated groups with BPF or levothyroxine only (Fig. 2c, d) and co-administrated groups (Fig. 2e, f) revealed an improvement in previous morphological changes, regular functional tubules and aggregated sperms in the cavity of tubules were noted.

\section{Disscussion}

\section{Thyroid gland}

The data obtained from the present investigation revealed that the treatment with carbimazole induced abnormal changes in thyroid tissues, a significant decrease in thyroid hormones (T4, T3, FT4 and FT3) and a significant increase in TSH levels compared to control group. These results are in line with those observed by many investigators (Hayat et al., 2010; Zbucki et al., 2007). Moreover, several reports have concluded that the decrease in thyroid hormones levels is due to the effect of carbimazole, which is anti-thyroid agent inhibits 5-deiodinase enzyme, thyroid peroxidase enzymes (TPO) and blocks intrathyroidal and peripheral conversion of T4-T3 (Manna et al., 2013; Moriyama et al., 2007). Furthermore, the hypothyroidism disease leading to disturbances of thyroid gland inhibits the synthesis of thyroid hormones, suppression of antioxidants and elevated of reactive oxygen species (Babu et al., 2011; Nakamura et al., 2007; Torun et al., 2009). In addition to that, Sushma et al. (2014) observed that carbimazole lowers serum levels of thyrotropin receptor auto-antibodies (TRAB). This lead to hypersecretion of pituitary TSH and an amplified increase in serum TSH level.Also, our results are consistent with Barakat and El-Masry (2015), who indicated that a reduction in serum FT3 and FT4 levels and a significant elevation in serum TSH level in rat orally administrated to carbimazole. Moreover, during pregnancy and lactation the administration of carbimazole induced alteration of the microstructure of thyroid gland in human newborn (Ali et al., 1995; Zaidi et al., 2004). Also, hypothyroidism was reported to induce oxidative stress in rat cerebellum and this resulting in tissues damage and apoptosis (Bhanja \& Chainy, 2010).

H\&E-stained sections of hypothyroid group in our study revealed negative homogenous eosinophilic colloid in thyroid follicles. This is similar to the results by Oncu et al. (2004), Hayat et al. (2010), El-Kalawy et al. (2012). In addition, intrafollicular adenomatosis consisted of an increase in the number of epithelial cells in the follicles, forming in some instances papillary projections into lumen, which occasionally divided the follicles in the middle or even completely oblitered the lumen, giving an appearance of adenomatous solidification as reported. Also, hypothyroid group revealed an increase in the follicular cell height compared with the control group. This was concomitant with the results of other researches 

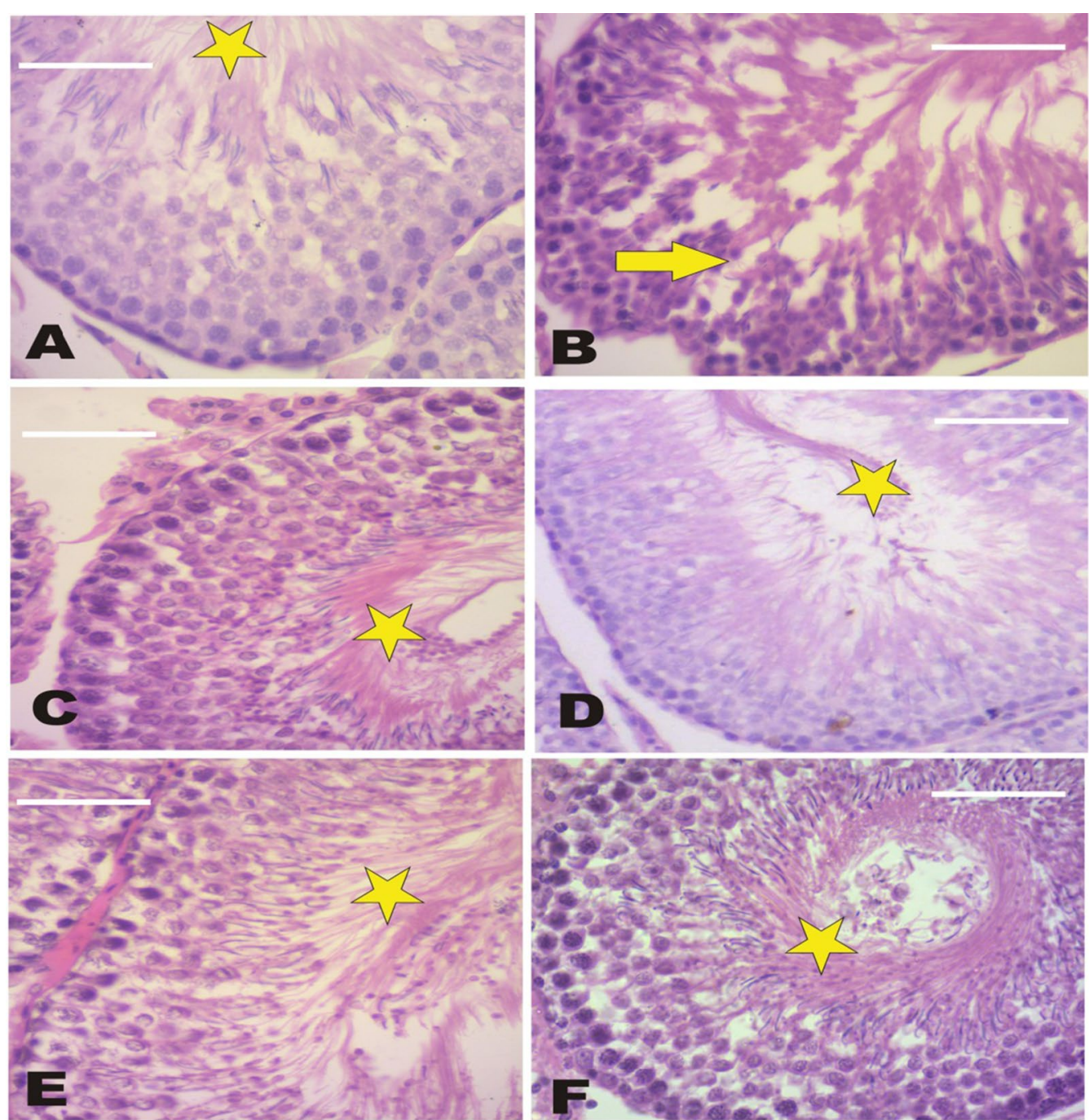

Fig. 2 a, c, d Photomicrograph of testes is showing normal seminiferous tubules with different stages of spermatogenic cells. Also, the lumen of seminiferous tubules was fully packed with sperms (stars). b Photomicrograph of hypothyroid testes showing marked morphological changes as degeneration of germinal epithelium and sloughing of germ cells into the tubular lumen (arrow) compared to control. e, f Photomicrograph of hypothyroid rat testes co-administrated with BPF and levothyroxine showing normal spermatogenic cells and increase of sperms (star) similar to those treated with either BPF (c) or levothyroxine (d) only as compared to hypothyroid animals. H\&E stain, scale bar $20 \mu \mathrm{m}$

(Ferreira et al., 2007). Histological alteration in our study could be attributed to low level of T4 that led to increased TSH level, which was responsible for the proliferative activity of follicular cellssimilar to that reported by El-Kalawy et al. (2012).

The present data demonstrated that, levothyroxine treated group showed a significant increase in thyroid hormones and a significant decrease in TSH levels compared to control group. Also, carbimazole co-treated withlevothyroxine group showed a significant improvement in all the tested parameters compared to carbimazole group. These results are in agreement with Barakat and El-Masry (2015) who postulated that in rats received eltroxin, thyroid hormones levels are increased and serum TSH level is decreased. This may result from alteration in the monodeiodination pathway. Accordingly, Saxena et al. (2012) explained that L-thyroxine treatment significantly increased the serum T3 and T4 concentrations. The increase in serum $\mathrm{T} 3$ is due to the stimulation in monodiodination of T4 in peripheral tissues, which is known to be the major process of its synthesis (Sari et al., 2016).

The histological observation of the normal thyroid and hypothyroid tissues treated with levothyroxine showing normal histological structure. These observations indicate that the levothyroxine ameliorate the general toxic 
effects extracted by carbimazole-induced hypothyroidism.Similar to those results, Serakides et al. (1999) and Torun et al. (2009) whoreported that, the hypothyroidism was accompanied by deleterious effects on thyroid gland and its hormones which were recovered by thyroxin treatment.

With regard to the treated group with BPF separated from bee venom, the results showed that, all the tested parameters increased significantly except the TSH which decreased significantly compared to normal control group. Also, in carbimazole co-treated with BPF group, a significant improvement detected compared to control and carbimazole group. These results agreed with Ludyanskii (1994) who observed that bee venom showed increased secretion of thyroid hormones. Furthermore, BPFs potentiate the effects of bradykinin both in vivo and in vitro (Machado et al., 2015). El-Sawi (2002) explained that the increase in thyroid hormones is due to the positive effect of bradykinin through the activation of prostaglandin synthesis which in turn stimulated the secretion of catecholamines (Strove, 1989) which consequently stimulates the synthesis of thyroid secretion (Ganong, 1995). Moreover, the activation of prostaglandin synthesis via the effect of bradykinin in Jelly fish crude venom enhanced the sensitivity of nervous system (Strove, 1989) which stimulated the secretion of thyroid gland (Babsky et al., 1989).

Also, the results indicated that there were a marked improvementin thyroid and hypothyroid tissues treated with BPF as compared to control group. These findings indicate that the BPF as a natural product have a protective effect on the thyroid gland structure and this may be useful for preventing or delaying the development of hypothyroidism and its complications. This effect is in agreement with the effect of Lemna minor extract in treatment of hypothyroidism (Kononeko \& Kravchenko, 2016). It is apparent that recovery of thyroid parenchyma is related to protection offered by BPF against hypothyroid status; this is similar to the effect of NigellaSativa oil (NSO) (Stelios et al., 2007). The therapeutic effect of bee venom and its extracted factor (BPF) against carbimazole induced hypothyroidism was most probably related to its antioxidant effect (Khalawi et al., 2013).

\section{2-Testis}

The data obtained from the present investigation revealed a significant decrease in luteinizing hormone $(\mathrm{LH})$, follicle stimulating hormone $(\mathrm{FSH})$ and testosterone levels in hypothyroid group induced by carbimazole compared to control group. These results are in agreement with Weng et al. (2007) who reported that hypothyroidism decreased the number and size of gonadotropes as the same as the plasma levels of
$\mathrm{LH}$ and FSH, implying that hypothyroidism probably caused gonadal dysfunction at the hypothalamus and pituitary levels. Also, anti-thyroid drugs may decrease production of sex hormone-binding globulin (SHBG) by the liver, thereby decreased SHBG lead to increase free androgen which inhibits the release gonadotropinreleasing hormone $(\mathrm{GnRH})$ secretion from anterior pituitary by negative feedback mechanism and therefore decreased FSH and LH levels (Mohamed \& Bushra, 2017).Decreased LH leads to decrease androgen. Thus, hypothyroidism may result in a reduction in SHBG and thyroid-binding prealbumin (ABP), leading to decrease LH, FSH and total serum testosterone levels (MacDonald et al, 2010).

The results indicated that, the histological examination of testes in carbimazole group showed different changes such as degenerative changes, cytoplasmic vacuoles, inhibition of spermatogenesis and absence of the sperms. These results attributed to the hypothyroidism diseases induced by carbimazole, this disease associated with adverse effects on male reproductive system (Jannini et al., 2000; Krassas \& Pontikides, 2004). Also, the results are in agreement with number of authers, they concluded that, the administrated hypothyroid drugs showed deleterious effects on testes such as, maturation arrest of spermatogenesis, reduction in the number of sertoli and leydig cells (Maran \& Aruldhas, 2002; Tahmaz et al., 2000), arrest the proliferation of germ cells and reduction of thyroid hormones levels (Hamouli-Said et al., 2007).

On the other hand, levothyroxine treated group showed a significant increase in LH and FSH levels while the testosterone level showing a non-significant increase compared to control group. Carbimazole co-treated with levothyroxine group showed a significant improvement in LH, FSH and testosterone levels compared to control and carbimazole groups. This improvement is due to direct stimulatory effect of thyroid hormone on leydig cells. Our results are consistent with Manna et al.,(2001, 2007) who conducted a study in which T3 appeared to increase LH receptors and steroidogenesis of leydig cells. T3 has also been seen to directly stimulate basal testosterone secretion which could be the result of its activating action on leydig cells (Maran et al., 2000). In addition to that, T3 is important in the maturation of the leydig cells in the interstitium of the testis. It is necessary to initiate the differentiation of mesenchymal cells into Leydig progenitor cells and works in concert with other hormones (LH, IGF-1) in promotion of Leydig cell development (Mendis-Handagams and Ariyarante, 2001). Bourget and Bradford (1987) and Longcope (2000) postulated that T4 increased SHBG concentration, increased peripheral aromatization of androstenedione, decreased total lipids, cholesterol and phospholipids in the testes, 
increased testosterone levels and increased testicular pyruvate kinase activity.

In the present study, treating hypothyroid rats with levothyroxine recovered the changes induced by carbimazole in testis. These findings were observed in previous investigators (Poppe et al., 2008; Torkoudes, et al., 2006). The hypothyroidism indicates disturbed thyroid tissues and decreasing thyroid hormones (Mark, 2011; ökten et al., 1996). Therefore, these observations may be attributed to the recovery of thyroid hormones levels by levothyroxine treatment. Because, levothyroxine drug has been available as a replacement for deficient thyroid hormones,it administrated to the body when the concentration of thyroid hormones decreased (Sarfaraz, 2004). In addition, the disturbed thyroid tissues by hypothyroidism were restored by thyroxin treatment (Torun et al., 2009). Also, thyroxin improved the testicular mass, cell damage (Mohamed \& Bushra, 2017), fertility and reverses hormonal abnormalities (Poppe et al., 2008; Torkoudes et al., 2006).On the other hand, reproduction is influences by many factors one of them is the thyroid hormones. It stimulates growth hormone secretion in birds, reptiles, rats and human (Roussen et al., 2002). Moreover, thyroid hormones play important role in the testicular development (Cooke \& Meisami, 1991), and regulate the proliferation of leydig and sertoli cells which leading to enhanced testis to produce sperms (Cooke et al., 1991; Mendis-Handagams and Ariyaranta, 2001).

In addition, BPF- treated group showed a significant increase in LH, FSH and testosterone levels compared to control group. In carbimazole co-treated with BPF group, a non-significant change is showed compared to control group. The improving effect of BPF in these male sex hormones and testes may be attributed to the indirect effect of bradykinin through the activation of prostaglandins synthesis which in turn stimulate gonadotrophic releasing hormone by acting on hypothalamus (Abu-Amra, 2001), causing the release of LHhormone which acts as a trigger for testosterone release (Frungieri et al., 2007). Accordingly, prostaglandins stimulate the release of testosterone from Leydig cells via the hypothalamo-hypophysial testis pathway (Suzuki-Yamamoto et al., 2007), or directly through the stimulation of testicular steroidogenesis. Moreover, prostaglandins stimulated cyclic AMP production in the testicle which in turn induced testosterone biosynthesis Milan (2002).

Moreover, it has been demonstrated that T3 increased a stimulatory growth factor of spermatogenesis, named Igf3 (insulin-like growth factor 3) (Morais et al., 2013). Igf3 is a sertoli cell growth factor, exclusively expressed in gonads, and FSH responsive (Nobrega et al., 2015). It has been shown that FSH promotes spermatogonial proliferation and differentiation via Igf3 (Nobrega et al., 2015), which is consistent with T3 stimulation of spermatogonial proliferation and differentiation in this species (Morais et al., 2013). Also, a significant recovery of testicular tissues was found in hypothyroid rats treated with BPF. These findings indicate that, BPF as natural product can protect and ameliorate reproductive system from deleterious effects of carbimazole induced hypothyroidism.

\section{Conclusion}

Hypothyroid rats treated with levothyroxine as a drug and BPF as a natural product showed an improvement of the complications induced by carbimazole in thyroid gland and testis. Therefore, BPF may be a benefical in treatment the complications of hypothyroidism.

\section{Abbreviations}

BPF: Bradykinin potentiating factor; TH: Thyroid hormones; LH: Leutinizing hormone; FSH: Follicular stimulating hormon.

Received: 6 July 2021 Accepted: 4 December 2021

Published online: 12 January 2022

\section{References}

Abd Elazeem, A., Mohammed, M. Z., \& Hassan, E. Z. (2016). Effect of experimentally induced hypothyroidism on the parotid gland of adult male albino rats and the possible role of thyroid hormone supplementation. British Journal of Science, 14(1), 2047-3745.

Abu-Amra, E. (2001). Physiological studies on diabetic male albino mice treated with a bradykinin potentiating factors of $\mathrm{BPF}_{7}$ and $\mathrm{BPF}_{9}$ on some physiological parameters. Egyptian Journal of Zoology, 3, 207-224.

Abu-Amra, E., Abd-El-Rehim, S. A., Lashein, F. M., Seleem, A. A., \& Shoaeb, H. S. I. (2015). The protective role of bradykinin potentiating factor on gastrointestinal ulceration induced by indomethacin in experimental animal. International Journal of Advanced Research, 3(6), 311-322.

Abu-Amra, E., Lashein, F. M., Seleem, A. A., \& Badr, A. H. (2018). Counter effect of bee venom and its extracted bradykinin-potentiating factor on acrylamide and chips administration-induced complications in the liver and kidney of male mice. The Journal of Basic and Applied Zoology, 79, 34

Ali, B. H., Bashir, A. A., \& Tanira, M. O. (1995). The effect of thyroxine or carbimazole treatment on gentamicin nephrotoxicity in rats. Human and Experimental Toxicology, 14(1), 13-17.

Babsky, B. E., Khodorov, B. I., Kositsky, G. I., \& Zubkow, A. A. (1989). Human physiology (6th ed.). Mir Publishers.

Babu, K., Jayaraai, I. A., \& Jeganathan, P. (2011). Effect of abnormal thyroid hormone changes in lipid peroxidation and antioxidant imbalance in hypothyroid and hyperthyroid patients. International Journal of Biological and Medical Research, 2(4), 1122-1126.

Barakat, H., \& El-Masry, S. (2015). Impact of folic acid on the neurotransmitters and oxidant-antioxidant balance in hypothyroid and hyperthyroid rats. International Journal of Pharma and Bio Sciences, 6(3), 1155-1165.

Bhanja, S., \& Chainy, G. B. N. (2010). PTU-induced hypothyroidism modulates antioxidant defence status in the developing cerebellum. Neuroscience, 28(3), 251-262.

Bourget, D., \& Bradford, M. W. (1987). Sexually aggressive men. Psychiatric Journal of the University of Ottawa, 12(3), 169-175.

Braverman, L. and Utiger, R. (2005). Introduction to hypothyroidism in Werner\& Ingbars. The Thyroid: a fundamental and clinical text.Ninth Edition, Eds: L Braverman and R Utiger. Pus: Lippincott Williams \& Wilkins. Chapter 46, pps.697-9.

Camargo, A., lanzer, D., Guerreiro, J. R., \& Serrano, S. M. (2012). Bradykininpotentiating peptides: Beyond captopril. Toxicon, 59, 516-523. 
Chihara, K., Iwaski, J., Minamitani, N., Kaja, H., Mastukura, S., Tmaki, N., Mastumoto, S., \& Fugita, T. (1982). Effect of vasoactive intestinal polypeptide on growth hormone secretion in perfused acromegalic pituitary adenoma tissues. Journal of Clinical Endocrinology and Metabolism, 54, 773-779.

Choksi, N. Y., Jahnke, G. D., Hilaire, C. S., \& Shelby, M. (2003). Role of thyroid hormones in human and laboratory animal reproductive health. Birth Defects Research, 68B, 479-491.

Cooke, P. S., \& Meisami, E. (1991). Early hypothyroidism in rats causes increased adult testis and reproductive size but does not change testosterone levels. Endocrinology, 129, 237-243.

Cooke, P. S., Hess, R. A., Porcelli, J., \& Meisami, E. (1991). Increased sperm production in adult rats after transient neonatal hypothyroidism. Endocrinology, 129, 244-248.

Daniels, E. G., \& Dayan, C. (2006). Hypothyroidism, etiology and presentation in fast facts: Thyroid Disorders, pub: Health Press Ltd, Chapter 4, pp. 69-78.

Diekman, M. J., Anghelescu, N., Endert, E., Bakker, O., \& Wiersina, W. M. (2000). Changles in plasma low-density lipoprotein (LDL) and high-density lipoprotein cholesterol in hypo-and hyperthyroid patients are related to changes in free thyroxine, not to polymorphisms in LDL receptor or cholesterol ester transfer protein genes. Journal of Clinical Endocrinology and Metabolism, 85, 1857-1862.

Drury, R. A. B., \& Wallington, E. A. (1976). Carleton's histological technique (pp. 48-58). Oxford University Press.

El-Defrawi, M. E., El-Defrawi, A. T., Burnett, J. W., Mioduszewski, R. J., Menking, D. E., \&Valdes, J. J. (1998). Toxicity of sea nettle toxin to human hepatocytes and the protective effects of phosphorylating and alkylating agents. Toxins, 36(2), 269-281.

El-Kalawy, A. M., Abo-Elnour, K. R., EIDeeb, F. D., \& Yousry, M. M. (2012). Histological and immunohistochemical study of the effect of experimentally induced hypothyroidism on the thyroid gland and bone of male albino rats. The Egyptian Journal of Histology., 1110-0559, 1-11.

El-Sawi, M. N. (2002). Effect of jelly fish crude venom on liver, thyroid and harderian glands of female mice. Journal of Applied Animal Research, 22, 97-104.

Fadeev, V. V. (2012). Problems of substitution treatment of hypothyroidism: Present and prospects: Clinical and Experimental. Thyroidology, 8(3), 12-17.

Ferreira, E., Silva, A. E., Serakides, R., Gomes, A. E. S., \& Cassali, G. D. (2007). Model of induction of thyroid dysfunctions in adult female mice. Arquivo Brasileiro De Medicina Veterinária e Zootecnia, 59(5), 1245-1249.

Ferreira, S. H. (1965). Abradykinin potentiating factor (BPF) present in the venom of Bothrops jararaca. British Journal of Pharmacology, 24, 163-169.

Frungieri, M. B., Gonzalez-Calvar, S. I., Matzkin, M. E., Mayerhofer, A., \& Calandra, R. S. (2007). Sources and functions ofprostaglandins in the testis: evidence for their relevance in male (in) fertility. Animal Reproduction, 4(3), 63-69.

Ganong, F. W.(1995). Review of medical physiology, 14th ed. Appleton and langue Norwalk, connecticuty Los Altos, California.

Gauldie, J., Hanson, J. M., Rumjanek, F. D., Shipolini, R. A., \& Vernon, C. A. (1976). The peptide components of bee venom. European Journal of Biochemistry, 61, 369-376.

Guo, L. Y., Zhu, J. F., \& Wu, X. F. (1999). Cloning of a cDNA encoding a nerve growth factor precursor from the Agkistrodon halyspallas. Toxicon, 37, 465-470.

Hamouli-Said, Z., Tahari, F., Hamoudi, F., \& Hadj-Bekkouche, F. (2007). Comparative study of the effects of pre and post natal administration of a thyroid drug on testicular activity in adult rat. Folia Histochemica Et Cytobiologica, 45, S51-S57.

Hayat, N. Q., Tahir, M., Munir, B., \& Sami, W. (2010). Effect of methimazoleinduced hypothyroidism on histological characteristics of parotid gland of albino rat. Journal of Ayub Medical College, Abbottabad JAMC, 22(3), 22-27.

Jain, R. K. (2003). Molecular regulation of vessel maturation. Nature Medicine, 9,685-693.

Jannini, E. A., Crescenzi, A., Rucci, N., et al. (2000). Ontogenetic pattern of thyroid hormone receptor expression in the human testis. Journal of Clinical Endocrinology and Metabolism, 85, 3453-3457.

Khalawi, A. A., Al-Robai, A. A., Khoja, S. M., \& Ali, S. S. (2013). Can NigellaSativa oil (NSO) reverse hypothyroid status induced by PTU in rat? Biochemical and Histological studies. Life Science Journal, 10(2), 802-811.

Kim, C. C. (2004). Bee venom treatment without the sting. U.S. Patent $0,081,702,4-29$.
Kononeko, A.and Kravchenko, V. (2016). Correcting effect of aqueous extract from duckweed Lemna Minor frond on morphological state of thyroid gland in rats with hypothyroidism. Agriculture and biological sciences. Original research article. 3-9

Krassas, G. E. (2000). Thyroid disease and female reproduction. Fertility and Sterility, 74, 1063-1070.

Krassas, G. E., \& Pontikides, N. (2004). Male reproductive function in relation with thyroid alterations. Best Practice and Research Clinical Endocrinology and Metabolism, 18(2), 183-195.

Lariviere, W. R., \& Melzack, R. (1996). The bee venom test: A new tonic-pain test. Pain, 66, 271-277.

Lashein, F. M., Abu-Amra, E., Seleem, A. A., \& Badr, A. H. (2018). Ameliorative effect of bee venom and its extracted bradykinin-potentiating factor on neurological alteration induced by acrylamide and chips administration. The Journal of Basic and Applied Zoology, 79, 2-13.

Lewis, R. J., \& Garcia, M. L. (2003). Therapeutic potential of venom peptides. Nature Reviews Drug Discovery, 2, 790-802.

Longcope, C., Feldman, H. A., \& Mckinday, J. B. (2000). Diet and sex hormonebinding globulin. Journal of Clinical Endocrinology and Metabolism., 85(1), 293-296.

Ludyanskii, E. A. (1994). Apiterapia. Vologda, Russia; poligrafist; 460pp.

Lui, X., Chen, D. W., Xie, L. P., \& Rongqing, Z. (2002). Effect of honey bee venom on proliferation of K1735M2 mouse melanoma cells in vitro and growth of murine B 16 melanomas in-vivo. Journal of Pharmacy and Pharmacology, 54, 1083-1089.

MacDonald, A. A., Herbison, G. P., Showell, M., \& Farquhar, C. M. (2010). The impact of body mass index on semen parameters and reproductive hormones in human males: A systemic review with meta-analysis. Human Reproduction Update, 16, 293-311.

Machado, R. A., Junior, L. G. M., Monteiro, N. K. V., Silva-Júnior, A. A., Portaro, F. C. V., Barbosa, E. G., Braga, V. A., \& Ferandes-pedrosa, M. (2015). Homology modeling, vasorelaxant and bradykinin-potentiating activities of a novel hypotension found in the scorpion venom from Tityus stigmurus. Toxicon, 101, 11-18

Mancini, A., Raimondo, S., Di, C., Persano, M., \& Pontecorvi, A. (2013). NonThyroidal IIIness: Physiopathology and Clinical Implications. Current Topics in Hypothyroidism with Focus on Development. https://doi.org/10.5772/ 5644

Manna, D.; Roy, G. and Mugesh, G. (2013). Antithyroid drugs and their analogues: synthesis, structure, and mechanism of action. Accounts of chemical research, 46: 2706-2715.\{12\}

Manna, P. R., Jo, Y., \& Stocco, D. M. (2007). Regulation of leydig cell steroidogenesis by extracellular signal-regulated kinase 1/2: Role of protein kinase and protein kinase C signaling. Journal of Endocrinology, 193, 53-63.

Manna, P. R., Roy, P., Clark, B. J., Stocco, D. M., \& Huhtaniemi, I. T. (2001). Interaction of thyroid hormone and steroidogenic acute regulatory (StAR) protein in the regulation of murine Leydig cell steroidogenesis. The Journal of Steroid Biochemistry and Molecular Biology, 76, 167-177.

Maran, R. R., \& Aruldhas, M. M. (2002). Adverse effects of neonatal hypothyroidism on Wistar rat spermatogenesis. Endocrine Research, 28, 141-154.

Maran, R. R., Arunakaran, J., \& Aruldhas, M. M. (2000). T3 directly stimulates basal and modulates $\mathrm{LH}$ induced testosterone and oestradiol production by rat Leydig cells in vitro. Endocrine Journal, 47, 417-428.

Mark, G. P. (2011). Saunders handbook of veterinary drugs small and large animal. 3th ed.

Mendis-Handagams, S. M., \& Ariyaratne, H. B. (2001). Differentiation of the adult Leydig cell population in the postnatal testis. Biology of Reproduction., 65(3), 660-671.

Milan, H. (2002). The effect of prostaglandin F 2a, oxytocin and gonadotropin releasing hormone on ejaculate characteristics in the dog. M. S. thesis, Blacksburg. Virgina, polytechnic institute and stat university.

Mitrou, P., Raptis, S. A., \& Dimitriadis, G. (2011). Thyroid disease in older people. Maturitas, 70(I), 5-9.

Mohamed, H. Z. E., \& Bushra, R. R. (2017). Effects of simultaneous melatonin administration on the testis of the experimentally induced hyper-and hypothyroidism in the adult male albino rat. The Egyptian Journal of Histology., 40(1), 52-65.

Montogomery, R. E. X., Dryer, R. L., Conway, T. W., and Spector, A. A. (1980). Biochemistry, A case oriented approach. Biochemical Education. Third edition, pp. 586-612. The C. V. Mos by company. 
Morais, R. D. V. S., Nóbrega, R. H., Gómez-Gonzales, N. E., Schmidt, R., Bogerd, J., França, L. R., \& Schulz, R. W. (2013). Thyroid hormone stimulates the proliferation of sertoli cells and single type a spermatogonia in adult Zebrafish (Danio rerio) testis. Endocrinology, 154, 4635-4676.

Moriyama, K., Tagami, T., Usui, T., et al. (2007). Antithyroid drugs inhibit thyroid hormone receptor-mediated transcription. Journal of Clinical Endocrinology and Metabolism, 92, 1066-1072.

Mustafa, S. A., Gouda, Z. A., Khalifa, M. E. A., \& Alkhodary, A. A. (2015). Levothyroxine drug ameliorates the pancreatic changes occurred after induced hypothyroidism in male albino rats. British Journal of Science, 12(1), 2047-3745.

Nakamura, H., Noh, J. Y., Itoh, K., Fukata, S., Miyauchi, A., \& Hamada, N. (2007). Comparison of methimazole and propylthiouracil in patients with hyperthyroidism caused by Grave's disease. The Journal of Clinical Endocrinology and Metabolism, 92(6), 2157-2162.

Nermine, K. M. S., \& Abeer, A. E. (2009). Immunological effects of honey bee venom in mice with intracerebral candidiasis. Journal of Medical Sciences, 9, 227-233.

Nobrega, R. H., Morais, R. D. V. S., Crespo, D., de Waal, P. P., Franca, L. R., Schulz, R. W., \& Bogerd, J. (2015). FSH stimulates spermatogonial proliferation and differentiation in Zebrafish via Igf3. Endocrinology, 156, 3804-3817.

Oncu, M., Kavakli, D., Gokcimen, A., Gulle, K., Orhan, H., \& Karaoz, E. (2004). Investigation on the histopathological effects of thyroidectomy on the seminiferous tubules of immature and adult rats. Urologia Internationalis, 73, 59-64.

Oršolić, N., Šever, L., Verstovšek, S., Terzić, S., \& Bašic, I. (2003). Inhibtion of mammary carcinoma cell proliferation in vitro and tumor growth in vivo by bee venom. Toxicon, 41, 861-870.

Ökten, A., Mungan, Z., \& Onuk, M. D. (1996). A case of propylthiouracil induced hepatotoxicity and hemolytic anemia. Turkish Journal of Gastroenterology, 7, 82-85.

Poppe, K., Velkeniers, B., \& Glinoer, D. (2008). The role of thyroid autoimmunity in fertility and pregnancy. Nature Clinical Practice Endocrinology and Metabolism, 4, 394-405.

Rébar, R. W., Erickson, G. F., \& Yen, S. C. C. (1982). Idiopathic premature ovarian failure: Clinical and endocrine characteristics. Fertility and Sterility, 37(1), 35-41.

Roberts, R. A. (1989). Bradykinin receptors: Characterization, distribution and mechanisms of signal transduction. Progress in Growth Factor Research, 1 , 237-252.

Roh, D. H., Kwon, Y. B., Kim, H. W., Ham, T. W., Yoon, S. Y., Kang, S. Y., Han, H. J., Lee, H. J., Beitz, A. J., \& Lee, J. H. (2004). Acupoint stimulation with diluted bee venom (api-puncture) alleviates thermal hyperalgesia in a rodent neuropathic pain model: Involvement of spinal alpha 2-adrenoceptors. The Journal of Pain, 5, 297-303.

Roussen, K., Le Belle, N., Sabaihi, M., Marchelidon, J., Schmits, M., \& Dufour, S. (2002). Evidence for a negative feedback in the control of eel growth by thyroid hormone. Journal of Endocrinology, 175, 603-613.

Salman, M. M. A. (2002). Serological, hematological and biochemical studies on bradykinin potentiating factor isolated from scorpion venom. Ph.D. Thesis, Faculty of Science, Ain Shams University. Cairo, Egypt. 12(1): 1-6.

Sarfaraz, N. K. (2004). Handbook of pharmaceutical manufacturing formulations: compressed solid product. CRC Press LLC; 151-2.

Sari, F. B., Soulimane, N. M., Merzouk, H., \& Loudjedi, L. (2016). High thyroid stimulating level contributes to nitric oxide and superoxide anion overproduction in women with hypothyroidism. International Journal of Health Science and Research, 6(3), 2249-9571.

Sauer, M. J., Foulkes, J. A., \& Cookson, A. D. (1981). Direct enzyme immunoassay of progesterone in bovine milk. Steroids, 38, 45-53.

Saxena, V., Dharamveer, G. R., \& Saraf, S. (2012). Ficus carica leaf extract in regulation of thyroidism using Elisa technique. Asian Journal of Pharmaceutical and Clinical Research, 2(2), 77-84.

Seleem, A. A. (2003). Effect of a natural bradykinin potentiating factor on cadmium toxicity during embryogenesis of white rat. M. SC. Thesis. Fac. of Science South Valley Univ., Sohag.

Serakides, R., Nunes, V. A., Santos, R. L., Cassali, G. D., \& Costa Neto, P. P. (1999). Histomorphometry and quantification of nuclear organizer region (NORs) in bovine thyroid containg methylthiouracil residues. Veterinary Pathology, 36(6), 574-582

Sonveaux, P. (2008). Provascular strategy: Targeting functional adaptions of mature blood vessel in tumors to selectively influence the tumor vascular reactivity and improve cancer treatment. Radiotherapy and Oncology, 86, 300-313.

Soos, M., \& Siddle, K. (1982). Characterization of monoclonal antibodies directed against human thyroid stimulating hormone. Journal of Immunological Methods., 51, 57-68.

Stelios, F., George, P., \& Agathocles, T. (2007). The role of iodine in the evolution of thyroid disease in Greece: From endemic goiter to thyroid autoimmunity. Horm, 6(1), 25-35.

Strove, E. A. (1989). In: Biochemistry, 1st ed. Prostaglandin. P: 399-400. Mir Publishers.

Sushma, M., Ramalingam, K., Naidu, N. J., \& Lakshmi, V.T. (2014). Lipid profile alterations and fasting blood glucose levels in primary hypothyroidism. International Journal of Research in Medical Sciences, 2(4), 1694-1698.

Suzuki-Yamamoto, T., Sugimoto, Y., Ichikawa, A., \& Ishimura, K. (2007). Co-localization of prostaglandin $\mathrm{F}$ synthase, cyclooxygenase-1 and prostaglandin F receptor in mouce Leydig cells. Histochemistry and Cell Biology, 128(4), 317-322.

Tahmaz, L., Gökalp, A., Kibar, Y., Kocak, I., Yalcin, O., \& özercan, Y. (2000). Effect of hypothyroidism on the testes in mature rats and treatment with levothyroxine and zinc. Andrologia, 32(2), 85-89.

Torkoudes, K. M., Skordis, N., \& Picolos, M. K. (2006). Infertility and thyroid disorders. Current Opinion in Obstetrics and Gynecology, 18, 446-451.

Torun, A. N., Kulaksizoglu, S., Kulaksizoglu, M., Pamuk, B. O., Isbilen, E., \& Tutuncu, N. B. (2009). Serum total antioxidant status and lipid peroxidation marker malondialdehyde levels in overt and subclinical hypothyroidism. Clinical Endocrinology, 70(3), 469-474.

Uotila, M., Ruoslahti, E., \& Engvall, E. (1981). Journal of Immunological Methods, 42,11 .

Weng, Q., Suzuki, A., Saita, E., Watanabe, G., Takahashi, S., Sedqyar, M., Taneda, S., \& Taya, K. (2007). Effects of methimazole-induced hypothyroidism on adrenal and gonadal functions in male Japanese quail (Coturnix japonica). Journal of Reproduction and Development, 53, 1335-1341.

Wisdom, G. B. (1976). Enzyme-immunoassay. Clinical Chemistry, 22(8), 1243-1255.

Wu, J., Akaide, T., Hayashida, K., Miyomoto, Y., Nakagawa, T., Miyakawa, K., Muller, E. W., \& Maeda, H. (2002). Identification of bradykinin receptors in clinical cancer specimen and murine tumor tissues. International Journal of Cancer, 98(1), 29-35.

Zaidi, T. M., Khan, A. A., Hasan, B. M., \& Faruq, A. N. (2004). Carbimazole induced thyroid histopathy in albino rats during development. Journal of Anatomical Society of India, 53(2), 14-17.

Zbucki, R., Winnicka, M., Sawicki, B. \& Szynaka, B. (2007). Alteration of parafollicular (C) cells activity in the experimental model of hypothyroidism in rats. Folia Histochemica Et Cytobiologica, 45(2), 115-121.

\section{Publisher's Note}

Springer Nature remains neutral with regard to jurisdictional claims in published maps and institutional affiliations.

\section{Submit your manuscript to a SpringerOpen ${ }^{\odot}$ journal and benefit from:}

- Convenient online submission

- Rigorous peer review

- Open access: articles freely available online

- High visibility within the field

- Retaining the copyright to your article

Submit your next manuscript at $\boldsymbol{\nabla}$ springeropen.com 